\title{
Sociobiology
}

RESEARCH ARTICLE - WASPS

\section{Temporal Polyethism and Life Expectancy of Workers in the Eusocial Wasp Polistes canadensis canadensis Linnaeus (Hymenoptera: Vespidae)}

\author{
VO TORRES ${ }^{1}$, E GIANNOTTI², WF ANTONIALLI-JUNIOR ${ }^{3}$ \\ 1 - Universidade Federal da Grande Dourados, Dourados, Mato Grosso do Sul, Brazil \\ 2 - Universidade Estadual Paulista "Julio de Mesquita Filho", Rio Claro, São Paulo, Brazil \\ 3 - Universidade Estadual de Mato Grosso do Sul, Dourados, Mato Grosso do Sul, Brazil
}

\section{Article History}

Edited by:

Gilberto M. M. Santos - UEFS, Brazil

Received 27 November 2012

Initial acceptance 31 January 2013

Final acceptance 14 February 2013

\section{Keywords}

Division of Labor, Worker Age,

Longevity, Foraging Activity

\section{Corresponding author}

Viviana de Oliveira Torres

Programa de Pós-graduação em

Entomologia e Conservação da Biodiversidade, Universidade Federal da Grande Dourados, Faculdade de

Ciências Biológicas e Ambientais, 241, 79804-970, Dourados, Mato Grosso

do Sul, Brazil.

E-Mail:vivianabio@yahoo.com.br

\begin{abstract}
The division of tasks among nestmates is one of the most important traits of the social Hymenoptera, and is responsible for their evolutionary success. This division of labor, which occurs among workers throughout their lives, is called temporal polyethism. This study investigated how temporal polyethism occurs, and its effects on the life expectancy of the eusocial wasp Polistes canadensis canadensis Linnaeus. To evaluate the different activities and determine longevity, newly emerged females were individually marked with colored dots on the mesosome. During their lives, workers perform 22 behavioral acts, and the Nonmetric Multidimensional Scaling analysis revealed a variation in the pattern of behaviors performed until the fifth week of life, i.e., close to their mean longevity. The mean life expectancy was $37.06 \pm 29.07$ days, with a mortality rate of $24.14 \%$ in the first week, coinciding with the onset of foraging activity. In other, lessderived species this began early in the life of the workers. The high entropy value $(\mathrm{H}=$ 0.750 ) reflects the high mortality rate in the first weeks of life.
\end{abstract}

\section{Introduction}

According to Wilson (1990), the non-reproductive division of labor among nestmates is the evolutionary advantage that most promoted the ecological success of social insects. This division of labor among workers that continues throughout their lifetimes is known as temporal polyethism; or if according to the morphology of the individual, morphological polyethism (Naug \& Gadagkar, 1998a). This phenomenon is most common in termites (Noroit, 1989) and ants (Hölldobler \& Wilson, 1990), and was recently discovered in a species of bee, Tetragonisca angustula (Latreille) (Grüter et al., 2011).

Temporal polyethism is evident in honey-bees (Seeley, 1995) and stingless bees (Sommeijer, 1984). Both tem- poral and morphological polyethism are less evident in Halictinae bees (Michener, 1974), Bombus (Cameron, 1989) and Polistinae wasps (Jeanne, 1991).

According to Shorter and Tibbetts (2008), social insects can also be divided into two categories, the leastderived or basal, and the most-derived. In most derived social insects there is a clear temporal polyethism, in which young workers care for the offspring, more often performing intra-nest tasks, while older workers forage and defend the colony, as described for Apis mellifera (Linnaeus) (Huang \& Robinson, 1996), Polybia occidentalis (Olivier) (O’Donnell, 2001), Pheidole dentata (Mayr) (Wilson, 1976), Trachymyrmex septentrionalis (Wheeler) (Beshers \& Traniello, 1996) and Agelaia pallipes (Olivier) (Nascimento et al., 2005), all species that are considered more derived within 
their respective groups.

Less-derived social insects have a less-clear division of labor: they are able to perform different tasks according to the needs of the colony (Beshers \& Fewell, 2001). Among the species that have been studied are Bombus griseocollis (De Geer) (Cameron, 1989), Bombus bifarius nearcticus (Handl) (O’Donnell et al., 2000), Polistes lanio lanio (Fabricius) (Giannotti \& Machado, 1994) and Belonogaster petiolata (De Geer) (Jeanne, 1991), in which no clear temporal polyethism was observed. However, other species such as Polistes canadensis (Linnaeus) (Giray et al., 2005), Ropalidia marginata (Lepeletier) (Naug \& Gadagkar, 1998b), Polistes metricus (Say) (Dew \& Michener, 1981), Polistes jadwigae (Dalla Torre) (Tsuchida, 1991) and Polistes dominula (Christ) (Pardi, 1950) have a clearer division of labor.

The degree of temporal polyethism also seems to be related to the size of the colony (Wilson, 1971; Thomas \& Elgar, 2003), since the division of labor among workers in general is directly proportional to colony size (Jeanne, 1986). In colonies of ants, bees, wasps and termites with thousands to millions of individuals, the division of tasks is clear and workers are highly specialized (Jeanne, 1986; Hölldobler \& Wilson, 1990). However, in small colonies of fewer than a hundred individuals, the workers tend to perform different daily tasks, showing "behavioral plasticity," for example, species of the genera Polistes (Post et al., 1988), Bombus (Cameron \& Robinson, 1990) and Belonogaster petiolata (Jeanne, 1991).

The different tasks performed by workers determine their life expectancy. Antonialli-Junior et al. (2007) found that the life expectancy of workers of Ectatomma planidens (Borgmeier) gradually decreases after the onset of foraging activity. Other studies conducted with wasps, by Miyanno (1980) with Polistes chinensis antennalis (Pérez) and Jeanne (1972) with Mischocyttarus drewseni (Saussure) found that the mortality rate increases after the wasps initiate extra-nest activities.

The first tasks performed by workers are usually intra-nest, which are safer and less costly. As the workers become older and more experienced, they perform outsidenest tasks (Wilson, 1971). Jeanne (1986) and Tofilski (2002) suggested that these sequences of tasks must maximize the workers' longevity.

This study investigated how temporal polyethism occurs and its effects on life expectancy and entropy in the eusocial wasp Polistes canadensis canadensis (Linnaeus), because of the importance of the division of labor in understanding the level of organization in social-insect colonies.

\section{Material and Methods}

The observations were made on colonies of $P$. $c$. canadensis constructed in urban areas of the central-west- ern Brazil (23 $56^{\prime} 17^{\prime \prime} \mathrm{S}$ and $\left.54^{\circ} 16^{\prime} 15^{\prime \prime} \mathrm{W}\right)$. The study was conducted between March 2005 and June 2006, totaling 200 hours of observation, in which 145 workers were monitored in 15 colonies.

Workers were marked as they emerged with dots of nontoxic paint on the mesosome, similarly to method used by Nakata (1996), allowing monitoring of their behaviors. Marking allowed us to collect data on life expectancy and to calculate the entropy for the workers.

\section{Temporal polyethism}

Marked workers were observed for one hour, three times a week, for qualification and quantification of behavioral acts performed throughout their lives, to characterize the temporal polyethism. We used the method of all occurrences ("ad libitum" sensu Altmann, 1974), which involves observing the animal's behavior including its entire performance, i.e., its movements and/or immobility. A description of how each action was executed was given by Torres et al. (2009).

The behavioral repertoire of the workers was grouped by week and analyzed by Nonmetric Multidimensional Scaling (NMDS). The Bray-Curtis similarity matrix was used for the NMDS ordination, based on the workers' behavioral repertoire according to the weeks of life. Behavioral data for the first six weeks (days 1 to 49) were used for the NMDS analysis, because by that time more than $50 \%$ of the workers had died.

\section{Determination of life expectancy and entropy}

The workers' life expectancy was calculated according to the methodology proposed by Carey (1993) and for the life-table construction and life-expectancy calculation, data were used for 145 workers, which were observed from emergence until death, by using the equation:

$$
T_{x}=\sum_{x=0}^{w} L_{x}
$$

Where: $T x=$ total number of days at age $\mathrm{x}$ of survivors until the last possible day of life; $\mathrm{x}=$ age interval of 1 day; $\mathrm{w}=$ maximum age in days reached by the last surviving individual; $\mathrm{Lx}=$ mean probability of surviving between successive ages, calculated as $\mathrm{Lx}=1 \mathrm{x}-(\mathrm{dx}) / 2 ; 1 \mathrm{x}=$ proportion of survivors among newly emerged workers in relation to age interval; $\mathrm{dx}=$ proportion of individuals that died between age $x$ and $x+1$, calculated as $d x=1 x-1 x+1$. The remaining life expectancy (ex) of individuals at the beginning of each interval was calculated as $\mathrm{ex}=\mathrm{Tx} / \mathrm{lx}$.

Entropy $(\mathrm{H})$, a measurement of the heterogeneity in the survival pattern, defined as the ratio between the number 
of days lost by the population due to deaths and the number of days that the workers lived, was calculated by the equation:

$$
H=\sum_{x=0}^{w} \frac{e_{x} d_{x}}{e_{0}}
$$

Where: $\mathrm{ex}=$ life expectancy at age $\mathrm{x} ; \mathrm{dx}=$ proportion of individuals that died between ages $\mathrm{x}$ and $\mathrm{x}+1$; $\mathrm{e} 0=$ life expectancy at age 0 ; and ew $=$ maximum age reached by the last surviving individual.

According to Carey (1993), the lower the value of entropy, the later individuals tend to die; and the higher the entropy value, the higher is the mortality in the initial intervals. Therefore, in populations in which individuals reach their maximum longevity, the entropy value is closer to zero; while in populations where the mortality rate is very high in the initial intervals, this value is closer to 1 .

\section{Results}

\section{Temporal polyethism}

The workers of $P$. c. canadensis performed 22 different types of tasks during their lives, and the frequency of each act varied according to age (Fig 1). The behaviors of vibrating wings, cleaning cells, larva-adult trophallaxis, suffering physical dominance, checking cells with antennae, walking on the nest or on the substrate, moving the gaster, self-grooming, adult-adult trophallaxis, checking cells and immobile on the nest were performed more often by younger workers. On the other hand, the behaviors of removing larvae from the nest, destroying cells, rubbing the gaster on the nest and oophagy were performed more often by older workers (Fig. 1).

With respect to foraging activity, the workers of $P$. c. canadensis started this behavior since the beginning of the first week of life, and intensified with the aging of the worker; however, the older females in the colonies did not forage (Fig 1).

Behaviors such as recognizing a newly emerged female, larviphagy, and applying oral secretion on the nest or on the substrate were performed with similar frequencies in both younger and older workers. The nonmetric multidimensional scaling analysis (NMDS: $\mathrm{R}^{2}=0.78, \mathrm{~F}=14.5, \mathrm{p}<0.02$, $\mathrm{gl}=4)$ showed significant variation in the behavior of workers until the fifth week of life (Fig 2).

\section{Determination of life expectancy and entropy}

The mean longevity of the workers was $37.06 \pm$ 29.07 days (1-126 days). The estimated life expectancy was $e x=36.56$ days just after emergence, increasing to $\mathrm{ex}=$ 40.00 days on the eighth day of life. From that time until the worker reached the maximum longevity, life expectancy decreased more gradually (Fig 3 ). The highest mortality rate occurred during the first week of life; $24.14 \%$ of the workers had died by the seventh day. Half of the workers did not reach 45 days, and only $9.65 \%$ exceeded 84 days (Fig 3).

The entropy found in $P$. c. canadensis was $\mathrm{H}=$ 0.750 (Fig 4), indicating a high mortality rate during the first intervals. The survival curve remained between 0.5 and 1.0 until the last life interval of workers (Fig 4). Because of the high number of deaths during the first days of life, the survival curve for this species has a convex shape. This curve is more pronounced until the 10th day of life and then increases more gradually until the last day of life.

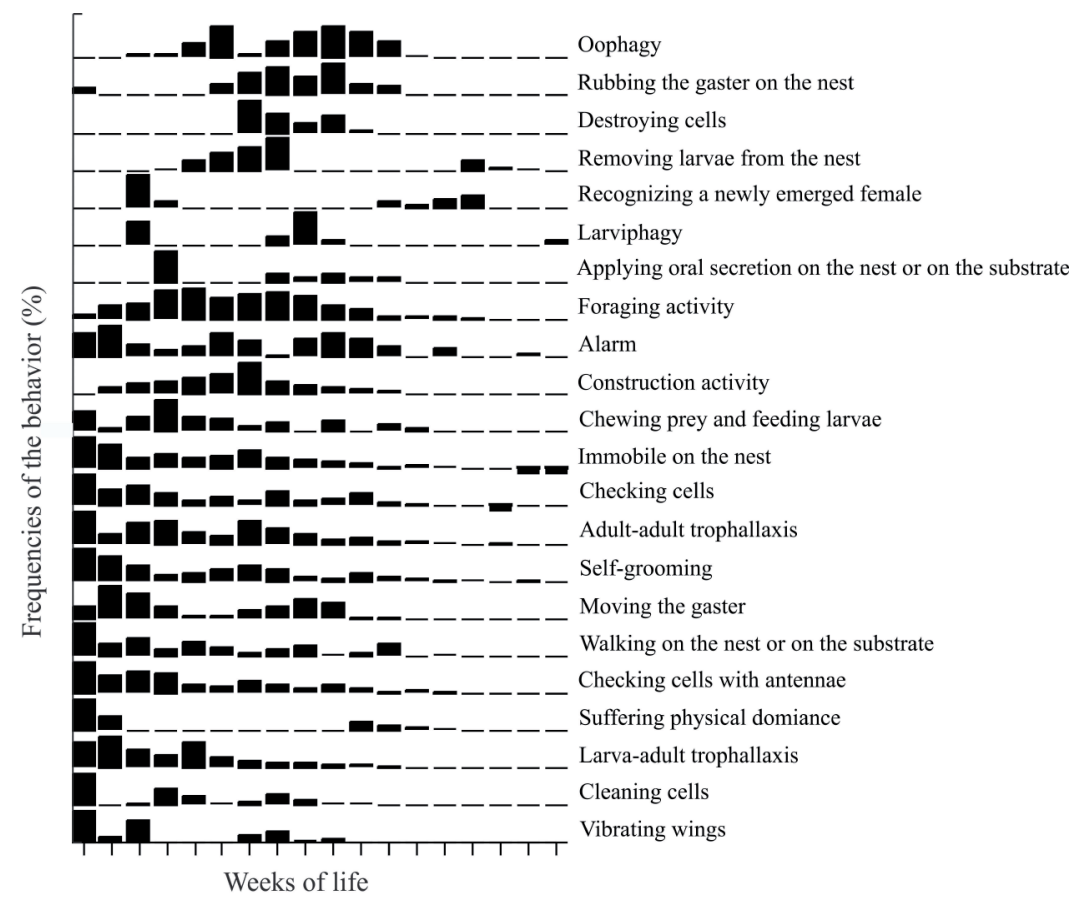

Figure 1. Frequency with which workers of Polistes canadensis canadensis performed the 22 behavioral acts throughout their lives. 


\section{Discussion}

The results found here demonstrate that the behavioral repertoire of the workers varies according to the age (Figs 1 and 2), although the NMDS indicated that this variation occurs only until the fifth week of life, close to the worker's mean life expectancy. The lack of a clear pattern of task execution after the fifth week shows that despite the existence of temporal polyethism, the workers have a strong "behavioral plasticity" after this age. Similar patterns were observed by Jeanne (1991) and Karsai and Wenzel (1998) in colonies with fewer than 100 individuals.

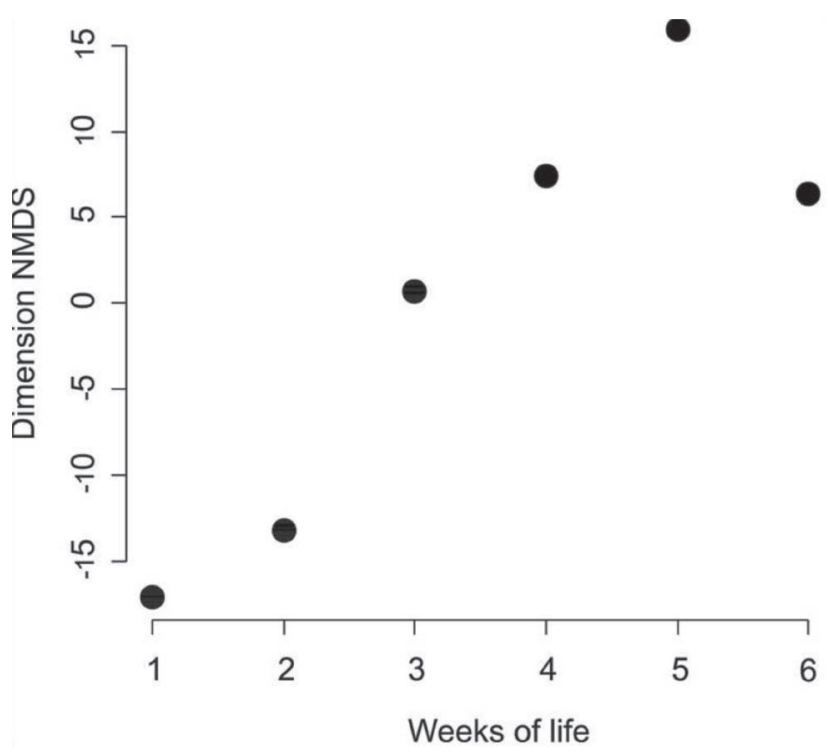

Figure 2. Ordination by Nonmetric Multidimensional Scaling (NMDS), indicating the behavioral variation according to age in workers of Polistes canadensis canadensis.

Although P.c. canadensis is considered a less-derived species, it displays temporal polyethism, which is considered "weak". Studies such as those of Jeanne (1991) and Giray et al. (2005) found that species of independent-foundation show little or no correlation between age and the tasks performed by workers. As seen in other studies, younger workers of $P$. c. canadensis perform mainly intra-nest tasks, and as they age they begin to perform extra-nest tasks. However, after the fifth week they perform a wider variety of tasks, both intra- and extra-nest.

Studies by O'Donnell (1998a), Naug and Gadagkar (1998b), Shorter and Tibbetts (2008) and Togni and Giannotti (2010) with Mischocyttarus mastigophorus (Richards), R. marginata, P. dominula and Mischocyttarus cerberus (Richards), respectively, have shown that even less-derived eusocial species have some degree of temporal polyethism. However, temporal polyethism is more evident and defined in the more-derived eusocial species, with large colonies and morphological differences between the castes (Naug \& Gadagkar 1998a), as observed in P. occidentalis (O’Donnell,
2001), A. pallipes (Nascimento et al., 2005) and Vespula germanica (Fabricius) (Hurd et al., 2007).

The degree of temporal polyethism also seems to be related to the size of the colony (Wilson, 1971; Thomas \& Elgar, 2003), since the division of labor among workers increases as the colony grows (Jeanne, 1986). There is a clear division of tasks and workers in colonies of ants, bees, wasps and termites with thousands to millions of individuals, and they are highly specialized (Hölldobler \& Wilson, 1990; Pie, 2002). However, in small colonies of fewer than 100 individuals, the workers tend to perform different daily tasks, as in species of the genera Polistes (Post et al., 1988; Reeve, 1991), Bombus (Cameron \& Robinson, 1990) and Belonogaster (Jeanne 1991).

Polyethism in M. mastigophorus is also affected by dominance interactions between queen and workers and between workers (O'Donnell, 1998a). According to O'Donnell (1998b), the pattern of independent foundation in these wasps suggests that the state of dominance in queens and workers affects the performance and the division of labor among individuals in the colony.

In $P$. c. canadensis, the queens become more aggressive with workers as they age. The increased aggressiveness of the queen with older workers is known as gerontocracy (Strassmann \& Meyer, 1983), in which the behaviors of physical dominance increase with the aging of the worker. This phenomenon was also observed by Pardi (1948) in Polistes gallicus (Linnaeus); Dew and Michener (1981) in P. metricus; and by Strassmann and Meyer (1983) in Polistes exclamans Viereck. However, West-Eberhard (1969) and Jeanne (1972), investigating colonies of Polistes erythrocephalus (Latreille) and M. drewseni, respectively, observed that younger females are in positions just below the queen.

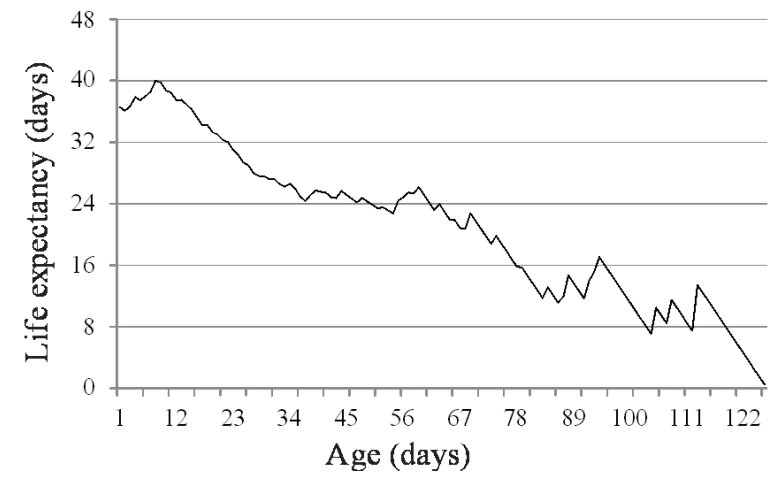

Figure 3. Life expectancy of workers of Polistes canadensis canadensis under field conditions.

Another factor responsible for behavioral changes with age is the changes in hormones, especially juvenile hormone (JH) (Giray et al., 2005). Shorter and Tibbetts (2008) have shown, for example, that foraging activity is initiated earlier by workers of $P$. dominula when newly emerged workers are treated with JH. However, in $R$. marginata, al- 


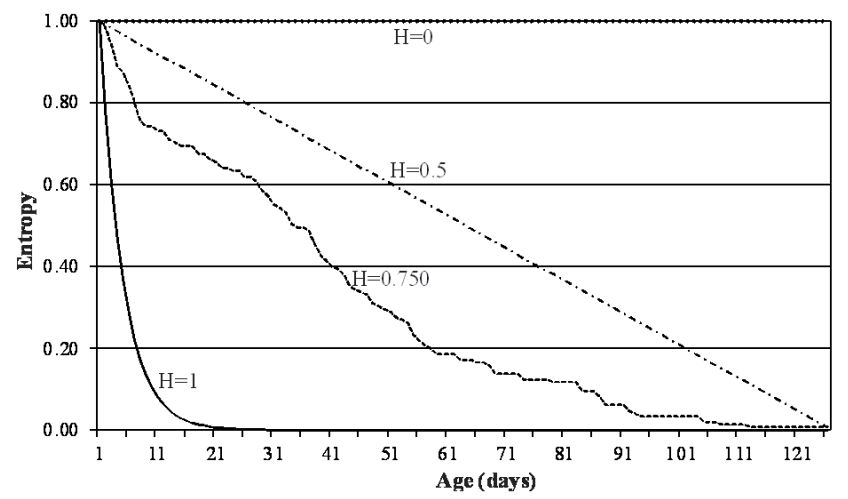

Figure 4. Survivorship curve of entropy in workers of Polistes canadensis canadensis $(\mathrm{H}=0.750)$ under field conditions.

though JH accelerates ovarian development, it does not affect the temporal polyethism (Agrahari \& Gadagkar, 2003).

The estimated mean longevity of the workers was close to that reported for P. c. antennalis (Miyano, 1980). The survival curve was relatively convex, similar to that described by Jeanne (1972) in M. drewseni, whose workers live on average 31 days. Giannotti (1999) described a mean life expectancy of only 14.1 days in Mischocyttarus cerberus styx (Richards), shorter than the species described above. These authors argue that the onset of foraging activity is directly linked to the longevity of the workers.

Life tables and survival curves of Polistes (Epicnemius) cinerascens (Saussure) (Giannotti, 1997) and Polistes lanio (Fabricius) (Giannotti \& Machado, 1999) also show high rates of mortality in the first age interval, which coincides with the beginning of foraging activity. This relationship was also observed by Simões and Zucchi (1980) in Protopolybia exigua exigua (Saussure) and by Post et al. (1988) in Polistes fuscatus variatus (Cresson). According to O'Donnell and Jeanne (1995), foraging activity implies a greater risk of predation, energy cost and physiological stress, thus reducing the life expectancy and longevity of the worker, and resulting in an entropy value closer to 1 . The high mortality rate in P. c. canadenis also coincides with the beginning of foraging activity, as $65 \%$ of workers began foraging activity in their first week of life.

The entropy value of $\mathrm{H}=0.750$ found here was close to that observed by Giannotti and Von Zuben (2000) for $P$. l. lanio $(\mathrm{H}=0.869)$ and $M$. cerberus $(\mathrm{H}=0.767)$, also lessderived species with small colonies in which workers begin foraging activity early.

Although P. c. canadensis has relatively small colonies, in which workers exhibit certain behavioral plasticity, they perform most of their repertoire in the first weeks of life; however, it is possible to perceive a clear division of tasks by the fifth week. Thus, longevity and entropy are directly influenced by foraging activity early in the first week of life.

\section{Acknowledgments}

To the Mato Grosso do Sul State University for the grants of PIBIC/UEMS, process No. 364/UEMS in March 2005. The "National Counsel of Technological and Scientific Development" (CNPq) for the grants to Antonialli-Junior, W.F. The authors thank also Janet W. Reid (JWR Associates) for the revision of the English text. Two anonymous reviewers provided valuable comments to the submitted manuscript.

\section{References}

Agrahari, M. \& Gadagkar, R. (2003). Juvenile hormone accelerates ovarian development and does not affect age polyethism in the primitively eusocial wasp, Ropalidia marginata. J. Insect Physiol.,49: 217-222.

Altmann, J. (1974). Observational study of behavior: sampling methods. Behaviour, 49: 227-267.

Antonialli-Junior, W.F., Tofolo, V.C. \& Giannotti, E. (2007). Population dynamics of Ectatomma planidens (Hymenoptera: Formicidae) under laboratory conditions. Sociobiology, 50: 1005-1013.

Beshers, S.N. \& Traniello, J.F.A. (1996). Polyethism and the adaptiveness of worker size variation in the attine ant Trachymyrmex septentrionalis. J. Insect Behav., 9: 61-83.

Beshers, S.N. \& Fewell, J.H. (2001). Models of division of labor in social insects. Annu. Rev. Entomol., 46: 413-440.

Cameron, S.A. (1989). Temporal patterns of division of labor among workers in the primitively eusocial bumble bee, Bombus griseocollis (Hymenoptera, Apidae). Ethology, 80: 137-151. DOI: 10.1111/j.1439-0310.1989.tb00735.x

Cameron, S.A. \& Robinson, G.E. (1990). Juvenile-hormone does not affect division of labor in bumble bee colonies (Hymenoptera, Apidae). Ann. Entomol. Soc. Am., 83: 626-631.

Carey, J.R. (1993). Applied demography for biologists. New York: Oxford University Press.

Dew, H.E. \& Michener, C.D. (1981). Division of labor among workers of Polistes metricus (Hymenoptera, Vespidae) - laboratory foraging activities. Insectes Soc., 28: 87-101.

Giannotti, E. (1997). Biology of the wasp Polistes (Epicnemius) cinerascens Saussure (Hymenoptera: Vespidae). An. Soc. Entomol. Bras., 26(1): 61-67.

Giannotti, E. (1999). Social organization of the eusocial wasp Mischocyttarus cerberus styx (Hymenoptera: Vespidae). Sociobiology, 33: 325-336.

Giannotti, E. \& Machado, V.L.L. (1994). Longevity, life table and age polyethism in Polistes lanio lanio (Hymenoptera, Vespidae), a primitive eusocial wasp. J.Adv. Zool., 15:95-101. 
Giannotti, E. \& Machado, V.L.L. (1999). Behavioral castes in the primitively eusocial wasp Polistes lanio Fabricius (Hymenoptera: Vespidae). Rev. Bras. Entomol., 43: 185-190.

Giannotti, E. \& Von Zuben, C.J. (2000). Entropy of adult wasps of Polistes lanio and Mischocyttarus cerberus (Hymenoptera, Vespidae), from colonies in field condictions. XXI Int. Congress Entomol., Brazil, p.62-62.

Giray, T., Giovanetti, M. \& West-Eberhard, M.J. (2005). Juvenile hormone, reproduction, and worker behavior in the neotropical social wasp Polistes canadensis. Proc. Natl. Acad. Sci. U.S.A., 102: 3330-3335.

Grüter, C., Menezes, C., Imperatriz-Fonseca, V.L. \& Ratnieks, F.L.W.A. (2012). A morphologically specialized soldier caste improves colony defense in a neotropical eusocial bee. Proc. Natl. Acad. Sci. U. S. A., 109(4): 1182-1186.

Hölldobler, B. \& Wilson, E.O. (1990). The ants. Cambridge: Harvard University Press.

Huang, Z.Y. \& Robinson, G.E. (1996). Regulation of honey bee division of labor by colony age demography. Behav. Ecol. Sociobiol., 39: 147-158.

Hurd, C.R., Jeanne, R.L. \& Nordheim, E.V. (2007). Temporal polyethism and worker specialization in the wasp, Vespula germanica. J. Insect Sci., 7(43): 1-13.

Jeanne, R.L. (1972). Social biology of the neotropical wasp Mischocyttarus drewseni. Bull. Mus. Comp. Zool., 3: 63150.

Jeanne, R.L. (1986). The evolution of the organization of work in social insects. Monit. Zool. Ital., 20: 119-133.

Jeanne, R.L. (1991). Polyethism. In K.G. Ross \& R.W. Matthews (Eds.), The Social Biology of Wasps (pp. 389 - 425). Ithaca, New York: Cornell University Press.

Karsai, I. \& Wenzel, J.W. (1998). Productivity, individuallevel and colony-level flexibility, and organization of work as consequence of colony size. Proc. Natl. Acad. Sci. U.S.A., 95: 8665-8669.

Michener, C.D. (1974). The social behavior of the bees: a comparative study. Cambridge: Harvard University Press.

Miyano, S. (1980). Life tables of colonies and workers in a paper wasp, Polistes chinensis antennalis, in central Japan (Hymenoptera: Vespidae). Res. Popul. Ecol., 22: 69-88.

Nakata, K. (1996). The difference in behavioral flexibility among task behaviors in a Ponerinae ant, Diacamma sp. Sociobiology, 27(2): 119-128.

Nascimento, F.S., Simões, D. \& Zucchi, R. (2005). Temporal polyethism and survivorship of workers of Agelaia pallipes. Sociobiology, 45: 377-387.

Naug, D. \& Gadagkar, R. (1998a). Division of labor among a cohort of young individuals in a primitively eusocial wasp.
Behav. Ecol. Sociobiol., 42: 247-254.

Naug, D. \& Gadagkar, R. (1998b). The role of age in temporal polyethism in a primitively eusocial wasp. Behav. Ecol. Sociobiol., 42: 37-47.

Noirot, C. (1989). Social structure in termite societies. Ethol. Ecol. Evol., 1: 1-17.

O’Donnell, S. (1998a). Dominance and polyethism in the eussocial wasp Mischocyttarus mastigophorus (Hymenoptera: Vespidae). Behav. Ecol. Sociobiol., 43: 327-331.

O'Donnell, S. (1998b). Reproductive caste determination in eusocial wasps (Hymenoptera: Vespidae). Annu. Rev. Entomol., 43: 323-346.

O'Donnell, S. (2001). Worker age, ovary development, and temporal polyethism in the swarm-founding wasp Polybia occidentalis. J. Insect Behav., 14: 201-212.

O’Donnell, S. \& Jeanne, R.L. (1995). Worker lipid stores decrease with outside-nest task-performance in wasps - implications for the evolution of age polyethism. Experientia, 51, 749-752.

O’Donnell, S., Reichardt, M. \& Foster, R. (2000). Individual and colony factors in bumble bee division of labor (Bombus bifarius nearcticus Handl; Hymenoptera, Apidae). Insectes Soc., 47: 164-170.

Pardi, L. (1948). Dominance order in Polistes wasps. Physiol. Zool., 21: 1-13.

Pardi, L. (1950). Recenti ricerche sulla divisione di lavoro negli imenotteri sociali. Boll. Zool., 17: 17-66.

Pie, M.R. (2002). Behavioral repertoire, age polyethism and adult transport in Ectatomma opaciventre (Formicidae: Ponerinae). J. Insect Behav., 15(1): 25-35.

Post, D.C., Jeanne, R.L. \& Erickson, E.H.Jr. (1988). Variation in behavior among workers of the primitively social wasp Polistes fuscatus variatus. In R.L. Jeanne (Ed.), Interindividual behavioral variability in social insects (pp. 283322). Boulder, Colo: Westview Press.

Reeve, H.K. (1991). Polistes. In K.G. Ross \& R.W. Matthews (Eds.), The social biology of wasps (pp. 99-149). Ithaca, New York: Cornell University Press.

Seeley, T.D. (1995). The wisdom of the hive: the social physiology of honey bee colonies. Cambridge: Harvard University Press.

Shorter, J.R. \& Tibbetts, E.A. (2008). The effect of juvenile hormone on temporal polyethism in the paper wasp Polistes dominulus. Insectes. Soc., 56: 7-13. DOI: 10.1007/s00040008-1026-1

Simões, D. \& Zucchi, R. (1980). Bionomics of Protopolybia exigua exigua (de Saussure). I. Age polyethism and life-table (Hymenoptera, Vespidae, Polybiini). Naturalia, 5: 79-87. 
Sommeijer, M.J. (1984). Distribution of labor among workers of Melipona favosa: age polyethism and worker oviposition. Insectes Soc., 31: 171-184.

Strassmann, J. E. \& Meyer, D.C. (1983). Gerontocracy in the social wasp, Polistes exclamans. Anim. Behav., 31: 431438.

Thomas, M.L. \& Elgar, M.A. (2003). Colony size affects division of labour in the ponerine ant Rhytidoponera metallica. Naturwissenschaften, 90: 88-92.

Tofilski, A. (2002). Influence of age polyethism on longevity of workers in social insects. Behav. Ecol. Sociobiol., 51: 234-237.

Togni, O.C. \& Giannotti, E. (2010). Colony defense behavior of the primitively eussocial wasp, Mischocyttarus cerberus is related to age. J. Insect Sci., 10 (136): 1-14. DOI: 10.1673/031.010.13601.
Torres, V.O., Antonialli-Junior, W.F. \& Giannotti, E. (2009). Divisão de trabalho em colônias da vespa social neotropical Polistes canadensis canadensis Linnaeus (Hymenoptera, Vespidae). Rev. Bras. Entomol., 53(4): 593-599.

Tsuchida, K. (1991). Temporal behavioral variation and division of labor among workers in the primitively eusocial wasp, Polistes jadwigae Dalla Torre. J. Ethol., 9: 129-134.

West-Eberhard, M. J. (1969). The social biology of polistine wasps. Misc. Publ. Mus. Zool. Univ. Mich., 140: 1-110.

Wilson, E.O. (1971). The Insect Societies. Cambridge: Harvard University Press.

Wilson, E.O. (1976). Behavioral discretization and the number of castes in an ant species. Behav. Ecol. Sociobiol., 1: $141-154$.

Wilson, E.O. (1990). Success and dominance in ecosystems: the case of the social insects. Oldendorf/Lube: Ecology Institute. 